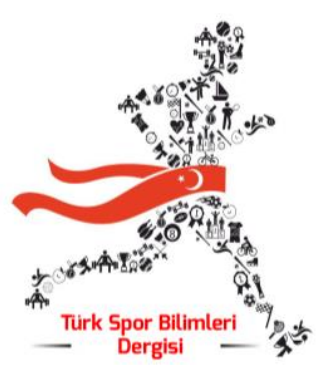

ISSN: 2636-848X

DOI: $10.46385 /$ tsbd. 974296

\section{Türk Spor Bilimleri Dergisi}

Türk Spor Bil Derg

Cilt 4, Say1 2

Ekim 2021, 60-69

The Journal of Turkish Sport Sciences J Turk Sport Sci

Volume 4, Issue 2 October 2021, 60-69

Aslihan BUKSUR ${ }^{1}$

Umut CANLI ${ }^{1}$

${ }^{1}$ Tekirdağ Namık Kemal Üniversitesi Beden Eğitimi ve Spor Yüksekokulu

\title{
İlkokul Öğrencilerinin Fiziksel Uygunluk Değişimleri: Sosyo-Ekonomik Açıdan Bir Değerlendirme
}

Özet

$\mathrm{Bu}$ araştırma ilkokul öğrencilerinde sosyo-ekonomik faktörlerin fiziksel uygunluk parametrelerine etkisinin incelenmesi amacı ile yapılmıștır. Özel bir ilkokulda öğrenim gören 44 kız öğrenci ve 39 erkek öğrenci olmak üzere toplam 83 öğrenci araştırmaya gönüllü olarak katılmıştır. Öğrencilerin fiziksel uygunluk düzeylerini değerlendirmek için Eurofit Test Bataryası kullanılmıştır. Eurofit test bataryası kapsamında; öğrencilerin vücut ağırlı̆̆1 ve boy uzunluğu değerleri ölçülmüstür. Motorik performansların belirlenmesinde ise, flamingo denge, diske dokunma, otur-uzan, durarak uzun atlama, mekik, bükülü kol asılma ve 5x10 metre mekik testleri kullanılmıştır. Demografik özelliklerin belirlenmesinde araştırmacılar tarafından hazırlanan kişisel bilgi formu kullanılmıștır. Verilerin normal dağılıp dağılmadığı basıklık ve çarpıklık değerleri ile kontrol edilmiștir. İstatistiksel analiz boyutunda; betimsel analiz (ortalama, standart sapma, medyan, min-maks değer, oran, frekans) ve tek yönlü varyans analizi (ANOVA) kullanılmıștır. Ayrıca, Scheffe post hoc analizlerinden yararlanılmıștır. Araștırmalardan elde edilen bulgularda; anne eğitim düzeyinin öğrencinin fiziksel uygunluk düzeylerini etkilemediği tespit edilmiştir ( $\mathrm{p}>0.05)$. Baba eğitim düzeyinin sadece flamingo denge test puanlarında anlamlı bir fark olusturduğu belirlenmistir $(\mathrm{p}<0.05)$. Ailelerinin aylık ortalama gelirleri ile oturuzan testi puanları arasında negatif yönlü zayıf bir ilişkinin olduğu tespit edilmiştir $(r=0.30 ; p<0.05)$. Sonuç olarak, anne eğitim düzeyinin öğrencilerin fiziksel uygunluk düzeylerini etkilemediği, baba eğitim düzeyinin ise öğrencilerin sadece denge düzeylerinde etkili olduğu belirlenmistir. Ailenin aylık ortalama gelirindeki artıs ile beraber öğrencilerin esneklik düzeylerinin zayıf düzeyde olsa azaldığı belirlenmiştir.

Anahtar Kelimeler: Fiziksel uygunluk, ilkokul öğrencileri, sosyo-ekonomik düzey

\section{Physical Fitness Changes of Primary School Students: A Socio-Economic Evaluation}

\begin{abstract}
This study was conducted to analyze effects of some socio-economic factors on physical fitness parameters in primary school students. A total of 83 students, 44 girls and 39 boys, studying at a private primary school voluntarily participated in the study. Eurofit Test Battery was used to assess physical fitness levels of students. Body weight and body height values were measured in accordance withEurofit test battery. In order to determine motoric performances flamingo balance, touching to the disc, sit and reach, standing long jump, sit up, bent-arm hang, and 5x10 meter shuttle tests were used. Personal information form prepared by the researchers was used to determine demographic properties. Kurtosis and skewness values were used to control whether data had normal distribution. At statistical analysis; descriptive analysis (medium, standard deviation, median, minimum-maximum value, rate, frequency) and unidirectional variance analysis (ANOVA) were used. In addition, Scheffe post hoc analysis were made. Study findings demonstrated that parents' level of education did not affect physical fitness levels of the students $(\mathrm{p}>0.05)$. Paternal education level was only demonstrated to make a significant difference in flamingo balance test scores $(\mathrm{p}<0.05)$. A weak negative relationship was found between average incomes of families and sit and reach test scores $(\mathrm{r}=0.30 ; \mathrm{p}<0.05)$. As a result, it was determined that maternal education level did not affect physical fitness levels of students, paternal education level was effective only on balance levels of students. It was found that with increase in monthly average income of family, there was a weak decrease in flexibility levels of students.
\end{abstract}

Keywords: Physical fitness, primary school students, socio-economic level
Sorumlu Yazar/Corresponding Author:

$$
\text { U. Canlı }
$$

e-mail: ucanli@,nku.edu.tr

Atıf için; Buksur, A. ve Canlı, U. (2021) İlkokul öğrencilerinin fiziksel uygunluk değişimleri: Sosyo-ekonomik açıdan bir değerlendirme. Türk spor bilimleri dergisi, 4(2), 60-69. 


\section{GİRİŞ}

Çocukların ilköğretim çağından başlayarak okul, dershane ve ev üçgeni arasına sıkıştıkları, çocukların zihinsel gelişimlerinin ön planda tutulduğu ancak ruhsal ve fiziksel gelişimlerinin göz ardı edildiği görülmektedir (Yüzgül ve Müniroğlu, 2001). Bununla beraber, ilköğretim öğrencileri mevcut eğitim sisteminin yoğun çalşşma programından dolayı pasif ve stresli yaşam koşullarının tehdidi altında kalmaktadır (Himes, 2006). Tüm bu etkenler ile birlikte ortaya çıkan durum hareketsizlik olarak tanımlanmaktadır. Hareketsizlik yaşam kalitesini olumsuz yönde etkileyerek çağımızda gençleri ve çocukları tehdit eden önemli bir sorun haline gelmektedir.

Çocukların sağlıklı ve bilinçli şekilde büyümeleri, olgunlaşıp gelişebilmeleri, hareketli yaşam stilini alışkanlık haline getirebilmeleri, genetik faktörlerin yanında onlara sunulmuş olan yaşam standartlarının yeterli düzeyde olması ile ilgilidir (Özer ve Özer, 2002). Çocuğun doğup büyüdüğü ülkenin coğrafi şartları, ailelerin sosyo-ekonomik statüleri ve kültürel değerleri, içinde bulunduğu toplumun örf ve adetleri, çocuğun ait olduğu ailenin hayat şartları gibi çevresel etkenler onun olgunlaşma, gelişimine etki etmektedir (Ball1, 2006). Belirtilen bu kavramlar içerisinde en önemli yeri aile kavramı almaktadır. Çünkü ailelerin içinde bulunduğu sosyal, ekonomik ve kültürel tüm durumlar, doğum öncesinden başlayarak tüm yaşamları boyunca çocuklara sağlanan eğitim, sağlık, beslenme durumları gibi etkenlerin çocukların gelişimlerini etkilediği görülmüştür (Muratlı, 2007; Yıldız, 2009). Sosyolojik anlamda aileye, işlevleri açışından yaklaşılacak olunursa, ailenin ekonomik işlevi, eğitim işlevi, serbest zamanları değerlendirme durumu gibi özellikleri geleneksel aile tipinden modern aile biçimine doğru ilerledikçe değiştiği ve farklılaştığı, bu farklılaşmadan dolayı çocukların farklı seviyelerde gelişim gösterdiği, olumlu ve olumsuz yönlerin ortaya çıktı̆̆ ifade edilmiştir (Saygın ve Özşaker, 2012; Bayraktar, 2001). Alt sosyo-ekonomik yetersizlikler nedeniyle, çocukların erken öğrenme becerilerini destekleyici materyaller ve yaklaşımlar sergileyemedikleri, maddi problemlerin ise, çocukların gelişimiyle yakından ilgilenilmesini ve gelişimlerinin desteklenmesini olumsuz yönde etkilediği ifade edilmiştir (Kandır ve Tümer, 2013).

Araştırmalarda yapılan değerlendirmeler neticesinde sosyo-ekonomik düzeyin çocuklarda fiziksel uygunluğu etkilediği de ortaya koyulmuştur (Güler ve Günay, 2004). Fiziksel uygunluğun vücut kompozisyonu parametresinin sosyo-ekonomik açısından yapılan bir değerlendirmesinde; sosyoekonomik düzeyi yüksek ve orta düzeydeki çocukların, sosyoekonomik düzeyi düşük akranlarına göre daha uzun ve daha iri oldukları belirlenmiştir (Akgün, 1997). Aynı zamanda, sosyo-ekonomik yapının hem çocuklarda hem de yetişkinlerde fiziksel uygunluk ve spor performans seviyeleri üzerinde etkisi olan önemli bir faktör olduğu bildirilmiştir (Malina, Bouchard ve Bar-or, 2004). Konu ile ilgili okul dönemi ve adölesan çocuklarda yapılan çalışmalar incelendiğinde; orta ve yüksek sosyo-ekonomik düzeye sahip aileler çocuklarına, düşük olan ailelere oranla daha iyi beslenme, sağılk hizmeti ve çocuk bakımı imkanları verebildikleri için (Bernink, Erich, Peltenburg, Zonderland, ve Huisveld, 1983) fiziksel uygunluklarının daha iyi olduğu belirtilmiştir (Goslin ve Burden, 1986; Pérez, D’Angelo ve Zabala, 1991Bazıçalışmalarda ise düşük sosyo-ekonomik düzeye sahip çocukların fiziksel uygunluklarının daha iyi oldukları belirtilmiştir (Tekelioğlu, 1999). Yine de, yüksek sosyoekonomik düzeye sahip çocukların sportif aktivitelere katılımlarının daha yüksek olduğu bilinmektedir (Pérez ve diğ., 1991). Oğuz (1998) farklı sosyo-ekonomik düzeye sahip okul dönemi çocuklarında; sosyo-ekonomik düzeyi yüksek çocukların patlayıcı güç ve hız gerektiren motor aktivitelerde daha yüksek, düşük sosyo-ekonomik düzeyde olanların ise denge, üst ekstremite kas kuvveti ve dayanıkllık testlerinde daha yüksek skorlara sahip olduklarını tespit etmiştir. Güler ve Günay (2004), sekiz-on yaş arası çocuklarda fiziksel uygunluk unsurları ile sosyo-ekonomik düzey arasındaki ilişkiyi araştırdıkları çalışmalarında, sosyo-ekonomik düzeyin çocuklarda fiziksel uygunluğu etkilediğini tespit etmişlerdir. Araştırma sonuçlarına göre (Güler ve Günay, 2004) yüksek sosyo-ekonomik düzeye sahip çocukların mekik kuvvet testinin daha yüksek, düşük sosyo-ekonomik düzeye sahip olanların ise barfiks kuvveti ve kardiyovasküler dayanıkll1k testlerinde daha iyi skorlar sergiledikleri bildirilmektedir. Farklı yaş kategorileri ve sınıf düzeylerinde bulunan çocukların fiziksel uygunluk düzeyleri sosyo-ekonomik değişkenler arasındaki ilişkiyi inceleyen araştırmaların olduğu görülmektedir, ancak bu araştırmaların sayısı 
oldukça azdır. Dolayısıyla, araştırmadan elde edilecek sonuçların alan yazına katkı sağlaması düşünülmektedir.

\section{Arastırmanin Amacı}

Buradan hareketle, araştırmanın amacı ilkokul öğrencilerinin ailelerinin sosyo-ekonomik unsurlarının öğrencilerin fiziksel uygunluk özelliklerini hangi düzeyde etkilediğini ortaya koymaktır.

\section{YÖNTEM}

\section{Araştırmanın Modeli}

Araştırma, genel tarama desenlerinden biri olan betimsel tarama modeline göre tasarlanmıştır. Tarama modelinin genel özellikleri incelendiğinde bir grubun belirli özelliklerini belirlemek için verilerin toplanmasının amaçlandığı ya da bir konuya ya da olaya ilişkin katılımcıların görüşlerinin, ilgi, beceri, yetenek ve tutum gibi özelliklerinin belirlendiği (Büyüköztürk, Çakmak, Akgün, Karadeniz ve Demirel, 2016) modeller olduğu görülmektedir.

\section{Araştırma Grubu}

Araştırmanın grubunu, özel bir ilkokulun 1.2.3. ve 4.sınıflarında öğrenim gören kız ve erkek katıllımcılar oluşturmaktadır. Araştırma grubu olarak tüm ilkokul kademesinde okuyan çocuklara ulaşılması hedeflenmiştir. Velilere detaylı araştırma kapsamını içeren bilgilendirilmiş gönüllü ve veli onam formu gönderilmiştir. Formu imzalayarak araştırmaya katılmayı kabul eden velilerin çocukları araştırmaya dahil edilmiştir. Bu doğrultuda $44 \mathrm{k}$ zz ve 39 erkek olmak üzere toplam 83 çocuk araştırmaya verilerin onamlarıyla katılmıştır. Çocukların yaş, cinsiyet ve sınıf düzeylerine ait bilgiler Tablo 1'de detaylandırılmıştır.

Tablo 1. Öğrencilerin Yaş Cinsiyet ve Sınıf Düzeylerine Yönelik Frekans ve Yüzdelik Dağılımları

\begin{tabular}{lcc}
\hline Değişkenler & Frekans & Yüzdelik Dağılım (\%) \\
\hline Yaş (yıl) & 3 & 3,6 \\
5 Yaş & 20 & 24,1 \\
6 Yaş & 23 & 27,7 \\
7 Yaş & 27 & 32,5 \\
8 Yaş & 10 & 12,0 \\
9 Yaş & & \\
\hline Cinsiyet & 44 & 53,0 \\
Kız & 39 & 47,0 \\
Erkek & & \\
\hline Sinıf düzeyi & 20 & 24,1 \\
\hline 1.Sinıf & 20 & 24,1 \\
2.Sinıf & 21 & 25,3 \\
3.Sinıf & 22 & 26,5 \\
4.Sinıf & & \\
\hline
\end{tabular}

\section{Veri Toplama Araçları}

Araştırmada demografik bilgileri içeren kişisel bilgi formu, Eurofit Test Bataryası öğrencilere uygulanmıştır. $\mathrm{Bu}$ araştırmada ölçüm bataryasına ilişkin bilgiler aşağıda açıklanmıştır.

\section{Eurofit Test Bataryas1}

\section{Boy uzunluğu ölçümü}

Katılımcıların boy uzunluğu ölçümleri ayakları çıplak durumda iken yapılmıştır. Ölçümler esnasında katılımcıların başları dik, ayak tabanları yere düz olarak basmış, dizler gergin, topuklar bitişik ve vücutların dik pozisyonda olmasına dikkat edilmiştir (Karakoç, 2009). Boy uzunluğu ölçümünde taşınabilir hassaslık derecesi $0.1 \mathrm{~cm}$ olan Mesilife 13539 marka stadiometre kullanılmıştır. Elde edilen değerler bilgi formuna santimetre olarak kaydedilmiştir. 


\section{Vücut ağırlı̆gı ölçümü}

Katılımcıların vücut ağıllıkları, hassaslık derecesi $0.01 \mathrm{~kg}$ olan Tanita BC $545 \mathrm{~N}$ marka Biyoelektrik İmpedans Analizörü ile ölçülmüştür. Katılımcıların ölçümleri çıplak ayak ve sadece şort, tişört kalacak şekilde ölçülmüştür. Değerler ölçüm formuna kg cinsinden kaydedilmiştir (Karakoç, 2009).

\section{Flamingo denge testi}

Statik denge özelliğinin belirlenmesinde kullanılan bir testtir. Katılımcılar denge aleti üzerine baskın ayaklarını kullanarak konumlarını devam ettirme çabasındadırlar. Test sürecinin başlaması için katılımcıların baskın olmayan ayağını kalçasına doğru bükerek aynı tarafta bulunan eli ile tutması istenmiştir. Katılımcılar denge aleti üzerinde tam olarak dengesini sağlayabilmesi için araştırmacılardan destek almalarına izin verilmiştir. Denge sağladığının hissedilip, yardım aşamasının bitmesi ile test başlatılmışır. Katılımcının amacı bir dakika boyunca denge aleti üzerinde belirlenen kurallar çerçevesinde dengesini korumasıdır. Katılımcı eli ile tuttuğu ayağını bırakır veya yere temas eder ise saniye durdurulur. Tekrar katılımcının dengesi sağlandıktan sonra süre devam eder. Bu süreç bir dakika oluncaya kadar devam eder. Katılımcının bir dakika içinde dengesini sağlama girişimi katılımcının skoru olarak kaydedilir (Hazar ve Taşmektepligil, 2008).

\section{Disklere dokunma testi}

Test protokolüne uygun olarak hazırlanmış test ekipmanı bir karton zemin üzerinde sağ ve sol bölümde iki disk ve disklerin ortasında bir kare bölüm olacak şekilde tasarlanmıştır. Katılımcının dominant olmayan eli karenin üzerinde bulunmaktadır. Dominant eli ile ise sağ ve sol bölümlerde bulunan disklere yirmi beş kez dokunması istenmiştir. Disklere dokunma testi iki defa yapılmıştır. Yirmi beş dokunma sonucunda belirlenen en düşük süre katılımcının skoru olarak saniye cinsinden kaydedilmiştir (Opstoel ve diğ., 2015).

\section{Otur-uzan testi}

Öğrencilerin hamstring esneklik düzeylerinin belirlenmesinde amacıyla kullanılmıştır. Testin gerçekleştirilebilmesi için sporcuların çıplak ya da çoraplı bir şekilde hazır olmaları istenmiştir. Öğrenciler oturma sehpası önünde uzun oturma pozisyonunda, ayak tabanları esneklik sehpasına temas ederek oturmuşlardır. Öğrencilerden dizlerini bükmemeleri ve gövdelerinden ileri doğru uzanarak sehpa üzerinde bulunan hareketli aparatı el parmak uçları ile ileri doğru sürüklemeleri ve uzanabildikleri en son seviyede 12 saniye sabit beklemeleri istenmiştir. Ölçüm yapan kişi, sporcuların yanında durarak dizlerinin bükülmesini engellemiştir. Aparatın bulunduğu en son konum santimetre cinsinden kaydedilmiştir. Ölçüm iki defa uygulanmıştır. En yüksek değer esneklik skoru olarak değerlendirilmiştir (Hazar ve Taşmektepligil, 2008).

\section{Durarak uzun atlama testi}

Katılımcı testin uygulanması için belirlenen çizginin arkasında pozisyonunu almıştır. Herhangi bir komut verilmeden, katılımcının kendini hazır hissettiğinde testi uygulaması istenmiştir. Katılımcının başlangıç noktasından sıçrayıp ayak topuklarının yere temas ettiği mesafe ölçülmüsstür. Durarak uzun atlama iki defa uygulanmıştır. İki testten en uzun olan mesafe katılımcının skoru olarak kaydedilmiştir (Altınkök, 2006).

\section{Mekik testi}

Katılımcıların kor bölgesi dayanıklılı̆̆nın belirlenmesine yönelik bir testtir. Katılımcılar yere uzanarak dizleri doksan derece olacak şekilde pozisyonlanını almışlardır. Katılımcıların mekik çekme esnasında ayaklarının yerden temasının kesilmemesi için araştırmacılar tarafindan gerekli tedbirler alınmıştır. Katılımcıların elleri ensede olacak şekilde ve mekik çekme sürecinin iniş evresinde omuzların yere temas etmesi ve kalkış evresinde de dirseklerin dizlere temas etmesi istenmiştir. Otuz saniye boyunca uygun çekilmiş mekik sayısı katılımcının skoru olarak kaydedilmiştir (Pekel, 2007). 


\section{Bükülü kol asılma testi}

Katılımcıların boy uzunluğuna göre hazırlanmış platformda, uygun bar tutuş şeklinin gösterilmesi ve katılımcının çenesinin bar hizasının altına gelinceye kadar yardım edilmesi araştırmacılar tarafindan yapılmıştır. Öğrencilerden mevcut pozisyonlarını korumaları istenmiş ve gözleri barın alına düştüğünde uygulama bitirilmiştir. Bu zamana kadar geçen süre katılımcının skoru olarak kaydedilmiştir (Zahner ve dig. ., 2006).

\section{$10 \times 5$ metre koşu testi}

İki duba arasında beş metre olacak şekilde uygulama yeri oluşturulmuştur. Katılımcının iki huni arasında bir kez gidiş ve dönüşü bir tur olarak belirlenmiştir. Katılımcının bu şekilde beş tur atması istenmiştir. Beş tur sonunda koşu süresi kaydedilmiş ve test sona erdirilmiştir (Opstoel ve diğ., 2015).

\section{Verilerin Toplanmas 1}

Etik kurul onayı için Tekirdağ Namık Kemal Üniversitesi Bilimsel Araştırma ve Yayın Etiği Kurulu Başkanllğı'na başvuruda bulunulmuş ve araştırma için gerekli etik kurul onay1 (Protokol No:2020.209.08.18) alınmıştır. Test prosedürleri teorik ve uygulamalı olarak araştırmacı tarafindan hem öğrencilere hem de velilerine detaylı bir şekilde anlatılmıştır. Kişisel bilgi formu velilere gönderilmiştir. Öğrencilerin öncelikli olarak boy uzunluğu ve vücut ağırlığı ölçümleri yapılmıştır. Daha sonra sırasıyla flamingo denge testi, otur-uzan esneklik testi, diske dokunma testi, durarak uzun atlama testi, bükülü kol asılma testi, mekik testi ve 10x5 metre mekik koşusu uygulanmıştır. Ölçümler ve testler, aynı sıra ile aynı araştırmacılar tarafindan katılımcılara uygulanmıştır. Tüm test seanslarından önce 5 dakikalık jogging ve ardından 5 dakikalık dinamik germelerden oluşan standart bir ısınma uygulanmıştır. Tüm testler, sirkadiyen ritimlerin çalışma sonuçları üzerindeki etkisini önlemek için günün aynı saatinde (17:30-19:30) yapıllmıştır.

\section{Verilerin Analizi}

Araştırmada elde edilen veriler SPSS 18.0 programı kullanılarak yapılmışıı. Verilerin analizinde araştırma grubunun özelliklerinin tanımlanması için tanımlayıcı istatistikler (ortalama, standart sapma, medyan, minmaks değer, oran, frekans vb.) kullanılmış ve tablolar yardımıyla ifade edilmiştir. Değişkenlerin karşılaştırmalarına geçilmeden önce normallik ve homojenlik varsayımlarının karşılanıp karşılanmadığı incelenmiştir (Tabachnick ve Fidell, 2013). Bu değerlendirme neticesinde değişkenlerin normal dağlım gösterdiği tespit edilmiştir. Daha sonra üç veya daha çok grup karşılaştırmalarında ise tek yönlü varyans analizi (ANOVA), alt grup karşılaştırmalarında Scheffe post hoc analizleri kullanılmıştır. Tek yönlü varyans analizinde değişkenler arasındaki ilişkinin gücünü hesaplamak için eta-kare (etki büyüklüğü) ( $\left.\eta^{2}\right)$ katsayısından faydalanılmıştır (Büyüköztürk ve diğ., 2016). Ölçümsel değişkeler arasındaki ilişkiler için Pearson Momentler Çarpımı Sıra Korelasyon Analizi kullanılmışır. İstatistiksel olarak $\mathrm{p}<0.05$ değeri anlamlı kabul edilmiştir.

\section{BULGULAR}

Bu bölümde araştırma sonuçlarından elde edilen cinsiyet, lisanslı spor yapma, okul türü, sınıf düzeyi, annebaba eğitim durumu değişkenlerine ve akademik erteleme ile serbest zaman egzersize katılım arasındaki ilişkiye ait bulgulara yer verilmiştir.

Tablo 2. Öğrencilerin Yaş Boy uzunluğu ve Vücut Ağıllı̆ına Yönelik Tanımlayıcı İstatistikler

\begin{tabular}{lcccc}
\hline Değişkenler & Minimum & Maksimum & Ortalama & Ss \\
\hline Yaş (yıl) & 5,0 & 9,0 & 7,25 & 1,06 \\
\hline Boy uzunluğu $(\mathrm{cm})$ & 115,0 & 150,0 & 131,10 & 7,93 \\
\hline Vücut ağırlı̆̆1 $(\mathrm{kg})$ & 17,0 & 50,0 & 28,30 & 6,77 \\
\hline
\end{tabular}

Araştırmaya katılan çocukların minimum yaş değeri 5 yaş, maksimum yaş değeri 9 yaş ve yaş ortalamaları $7.25 \pm 1.06$ yll olarak tespit edilmiştir. Çocukların minimum boy uzunluğu $115.0 \mathrm{~cm}$, maksimum boy uzunluğu $150.0 \mathrm{~cm}$, boy uzunluğu ortalamaları ise $131.10 \pm 7.93 \mathrm{~cm}$ olarak belirlenmiştir. Çocukların 
minimum vücut ağırlığ1 $17 \mathrm{~kg}$, maksimum vücut ağırllğ1 $50 \mathrm{~kg}$ ve vücut ağırlı̆̆1 ortalamalar1 $28.30 \pm 6.77$ olarak tespit edilmiştir (Tablo 2).

Tablo 3. Öğrencilerin Fiziksel Uygunluk Parametrelerine Yönelik Tanımlayıcı İstatistikler

\begin{tabular}{lcccc}
\hline Değişkenler & Minimum & Maksimum & Ortalama & Ss \\
\hline Flamingo denge testi (n) & 2,00 & 28,00 & 13,22 & 6,85 \\
\hline Diske dokunma testi (sn) & 13,70 & 36,70 & 25,14 & 5,29 \\
\hline Otur-uzan testi (cm) & 16,00 & 43,00 & 29,14 & 4,70 \\
\hline Durarak uzun atlama testi (cm) & 40,00 & 165,00 & 104,78 & 23,89 \\
\hline Mekik testi (n) & 5,00 & 27,00 & 14,48 & 5,00 \\
\hline Bükülü kol asılma testi (sn) & 1,00 & 15,60 & 4,76 & 3,52 \\
\hline 5x10 metre mekik koşusu testi (sn) & 30,50 & 57,20 & 42,15 & 6,95 \\
\hline$*$ n= adet & & &
\end{tabular}

Araştırmaya katılan öğrencilerin flamingo denge testi değerlerine bakıldığında minimum $2.00 \mathrm{n}$, maksimum $28.00 \mathrm{n}$, flamingo denge testi ortalamaları ise $13.22 \pm 6.85$ sayı olarak tespit edilmiştir. Öğrencilerin diske dokunma testi değerlerine bakıldığında minimum $13.70 \mathrm{sn}$, maksimum $36.70 \mathrm{sn}$, diske dokunma testi ortalamaları ise $25.14 \pm 5.29$ sn olarak tespit edilmiştir. Öğrencilerin otur-uzan testi değerlerine bakıldığında minimum $16.00 \mathrm{~cm}$, maksimum $43.00 \mathrm{~cm}$, otur-uzan testi ortalamalar1 ise $29.14 \pm 4.70 \mathrm{~cm}$ olarak tespit edilmiştir. Öğrencilerin durarak uzun atlama testi değerlerine bakıldığında minimum $40.00 \mathrm{~cm}$, maksimum $165.00 \mathrm{~cm}$, durarak uzun atlama testi ortalamaları ise $104.84 \pm 23.89 \mathrm{~cm}$ olarak tespit edilmiştir. Öğrencilerin mekik testi değerlerinin minimum $5.00 \mathrm{n}$, maksimum $27.00 \mathrm{n}$, mekik testi ortalamaları ise 14.48 \pm 5.00 sayı olarak tespit edilmiştir. Çocukların bükülü kol asılma testi değerlerinin minimum $1.00 \mathrm{sn}$, maksimum 15.60 sn, bükülü kol asılma testi ortalamaları ise $4.76 \pm 3.52$ sn olarak tespit edilmiştir. Öğrencilerin 5x10 metre mekik koşusu testi değerlerinin minimum 30.50 sn, maksimum 57.20 sn, 5x10 metre mekik koşusu testi ortalamaları ise $42.15 \pm 6.95$ sn olarak tespit edilmiştir (Tablo 3).

Tablo 4. Öğrencilerin Fiziksel Uygunluk Parametrelerinin Anne Eğitim Düzeyi Açısından Karşılaştırması

\begin{tabular}{|c|c|c|c|c|c|c|c|c|c|c|c|}
\hline \multirow[t]{2}{*}{ Değgişkenler } & \multicolumn{2}{|c|}{$\begin{array}{c}\text { İlköğretim } \\
\mathrm{n}=10\end{array}$} & \multicolumn{2}{|c|}{$\begin{array}{c}\text { Ortaöğretim } \\
n=26\end{array}$} & \multicolumn{2}{|c|}{$\begin{array}{c}\text { Yükseköğretim } \\
\mathrm{n}=47\end{array}$} & \multirow{2}{*}{$\begin{array}{c}\text { Varyansın } \\
\text { Kaynağ1 }\end{array}$} & \multirow{2}{*}{$\begin{array}{c}\text { Kareler } \\
\text { Toplamı }\end{array}$} & \multirow{2}{*}{$\begin{array}{c}\text { Kareler } \\
\text { Ort. }\end{array}$} & \multirow[t]{2}{*}{$\mathbf{F}$} & \multirow[t]{2}{*}{$\mathrm{p}$} \\
\hline & $\overline{\mathrm{X}}$ & Ss & $\bar{x}$ & Ss & $\overline{\mathrm{X}}$ & Ss & & & & & \\
\hline $\begin{array}{l}\text { Boy uzunluğu } \\
(\mathrm{cm})\end{array}$ & 133,70 & 7,94 & 130,96 & 6,40 & 130,63 & 8,71 & $\begin{array}{c}\text { Gruplar arası } \\
\text { Gruplar içi } \\
\text { Toplam }\end{array}$ & $\begin{array}{c}78,111 \\
5085,913 \\
5164,024 \\
\end{array}$ & $\begin{array}{l}39,056 \\
63,574\end{array}$ & 0,61 & 0,54 \\
\hline $\begin{array}{l}\text { Vücut ağırlı̆̆1 } \\
\text { (kg) }\end{array}$ & 30,60 & 5,89 & 27,96 & 5,07 & 28,00 & 7,72 & $\begin{array}{c}\text { Gruplar aras1 } \\
\text { Gruplar içi } \\
\text { Toplam }\end{array}$ & $\begin{array}{c}60,108 \\
3699,362 \\
3759,470\end{array}$ & $\begin{array}{l}30,054 \\
46,242\end{array}$ & 0,65 & 0,52 \\
\hline $\begin{array}{l}\text { Flamingo } \\
\text { denge testi (n) }\end{array}$ & 12,20 & 7,58 & 13,64 & 7,32 & 13,38 & 6,57 & $\begin{array}{c}\text { Gruplar aras1 } \\
\text { Gruplar içi } \\
\text { Toplam }\end{array}$ & $\begin{array}{c}12,060 \\
3844,591 \\
3856,651\end{array}$ & $\begin{array}{c}6,030 \\
48,057\end{array}$ & 0,12 & 0,88 \\
\hline $\begin{array}{l}\text { Diske } \\
\text { dokunma testi } \\
(\mathrm{sn})\end{array}$ & 25,08 & 2,36 & 24,28 & 5,10 & 25,63 & 5,83 & $\begin{array}{c}\text { Gruplar arası } \\
\text { Gruplar içi } \\
\text { Toplam }\end{array}$ & $\begin{array}{c}30,684 \\
2265,744 \\
2296,428\end{array}$ & $\begin{array}{l}15,342 \\
28,322\end{array}$ & 0,54 & 0,58 \\
\hline $\begin{array}{l}\text { Otur-uzan } \\
\text { testi }(\mathrm{cm})\end{array}$ & 27,90 & 4,70 & 29,92 & 3,73 & 28,97 & 5,18 & $\begin{array}{c}\text { Gruplar arası } \\
\text { Gruplar içi } \\
\text { Toplam }\end{array}$ & $\begin{array}{c}32,540 \\
1781,725 \\
1814,265\end{array}$ & $\begin{array}{l}16,270 \\
22,272\end{array}$ & 0,73 & 0,48 \\
\hline $\begin{array}{l}\text { Durarak uzun } \\
\text { atlama testi } \\
(\mathrm{cm})\end{array}$ & 94,80 & 17,15 & 107,38 & 21,15 & 105,46 & 26,29 & $\begin{array}{c}\text { Gruplar arası } \\
\text { Gruplar içi } \\
\text { Toplam }\end{array}$ & $\begin{array}{c}1194,640 \\
45637,456 \\
46832,096\end{array}$ & $\begin{array}{l}597,320 \\
570,468\end{array}$ & 1,04 & 0,35 \\
\hline $\begin{array}{l}\text { Mekik testi } \\
\text { (n) }\end{array}$ & 15,80 & 4,41 & 15,23 & 5,14 & 13,78 & 5,02 & $\begin{array}{l}\text { Gruplar arası } \\
\text { Gruplar içi } \\
\text { Toplam }\end{array}$ & $\begin{array}{c}54,635 \\
1998,088 \\
2052,723\end{array}$ & $\begin{array}{l}27,318 \\
24,976\end{array}$ & 1,09 & 0,34 \\
\hline $\begin{array}{lr}\begin{array}{l}\text { Bükülü } \\
\text { asılma } \\
\text { (sn) }\end{array} & \text { testi } \\
\end{array}$ & 5,57 & 4,54 & 4,36 & 2,97 & 4,82 & 3,61 & $\begin{array}{c}\text { Gruplar arası } \\
\text { Gruplar içi } \\
\text { Toplam }\end{array}$ & $\begin{array}{c}10,926 \\
1008,462 \\
1019,388\end{array}$ & $\begin{array}{c}5,463 \\
12,606\end{array}$ & 0,43 & 0,65 \\
\hline $\begin{array}{l}\text { 5x10 metre } \\
\text { mekik koşusu } \\
\text { testi (sn) }\end{array}$ & 40,30 & 6,52 & 41,77 & 6,75 & 42,75 & 7,20 & $\begin{array}{c}\text { Gruplar arası } \\
\text { Gruplar içi } \\
\text { Toplam }\end{array}$ & $\begin{array}{c}54,922 \\
3909,747 \\
3964,669\end{array}$ & $\begin{array}{l}27,461 \\
48,872\end{array}$ & 0,56 & 0,57 \\
\hline
\end{tabular}


Öğrencilerin anne eğitim düzeyi açısından fiziksel uygunluk parametrelerinin karşılaştırmasında; boy uzunluğu, vücut ağırllğı, flamingo denge testi, diske dokunma testi, otur-uzan testi, durarak uzun atlama testi, mekik testi, bükülü kol asılma testi, $5 \times 10$ metre mekik koşu testi değerlerinde anlamlı bir farklılık tespit edilmemiştir ( $\mathrm{p}>0.05$ ) (Tablo 4).

Tablo 5. Öğrencilerin Fiziksel Uygunluk Parametrelerinin Baba Eğitim Düzeyi Açısından Karşılaştırması

\begin{tabular}{|c|c|c|c|c|c|c|c|c|c|c|c|c|}
\hline \multirow[t]{2}{*}{ Değişkenler } & \multicolumn{2}{|c|}{$\begin{array}{c}\text { İlköğretim } \\
\mathrm{n}=10\end{array}$} & \multicolumn{2}{|c|}{$\begin{array}{c}\text { Ortaöğretim } \\
\mathrm{n}=25\end{array}$} & \multicolumn{2}{|c|}{$\begin{array}{c}\text { Yükseköğretim } \\
\mathrm{n}=48\end{array}$} & \multirow{2}{*}{$\begin{array}{l}\text { Kareler } \\
\text { Toplamı }\end{array}$} & \multirow{2}{*}{$\begin{array}{c}\text { Kareler } \\
\text { Ort. }\end{array}$} & \multirow[t]{2}{*}{$\mathbf{F}$} & \multirow[t]{2}{*}{$\mathrm{p}$} & \multirow{2}{*}{$\begin{array}{c}\text { Scheffe } \\
\text { post } \\
\text { hoc }\end{array}$} & \multirow[t]{2}{*}{$\eta^{2}$} \\
\hline & $\overline{\mathrm{X}}$ & Ss & $\overline{\mathbf{X}}$ & Ss & $\overline{\mathrm{X}}$ & Ss & & & & & & \\
\hline $\begin{array}{l}\text { Boy uzunluğu } \\
(\mathrm{cm})\end{array}$ & 131,70 & 7,31 & 132,64 & 7,43 & 130,18 & 8,31 & $\begin{array}{c}102,852 \\
5061,172 \\
5164,024 \\
\end{array}$ & $\begin{array}{l}51,426 \\
63,265\end{array}$ & 0,81 & 0,44 & - & - \\
\hline $\begin{array}{l}\text { Vücut ağırlı̆̆1 } \\
\text { (kg) }\end{array}$ & 28,60 & 5,42 & 29,76 & 6,62 & 27,47 & 7,07 & $\begin{array}{c}86,531 \\
3672,939 \\
3759,470\end{array}$ & $\begin{array}{l}43,265 \\
45,912\end{array}$ & 0,94 & 0,39 & - & - \\
\hline $\begin{array}{l}\text { Flamingo denge } \\
\text { testi (n) }\end{array}$ & 8,20 & 4,58 & 14,84 & 7,74 & 13,43 & 6,37 & $\begin{array}{c}319,878 \\
3536,773 \\
3856,651 \\
\end{array}$ & $\begin{array}{c}159,939 \\
44,210\end{array}$ & 3,61 & $0,03 *$ & $\begin{array}{c}1-2 \\
p=0,03\end{array}$ & 0,03 \\
\hline $\begin{array}{l}\text { Diske dokunma } \\
\text { testi (sn) }\end{array}$ & 25,37 & 2,72 & 23,54 & 4,30 & 25,93 & 5,99 & $\begin{array}{c}94,032 \\
2202,396 \\
2296,428\end{array}$ & $\begin{array}{l}47,016 \\
27,530\end{array}$ & 1,70 & 0,18 & - & - \\
\hline $\begin{array}{l}\text { Otur-uzan testi } \\
(\mathrm{cm})\end{array}$ & 28,40 & 4,76 & 29,28 & 4,04 & 29,22 & 5,07 & $\begin{array}{c}6,346 \\
1807,919 \\
1814,265\end{array}$ & $\begin{array}{c}3,173 \\
22,599\end{array}$ & 0,14 & 0,86 & - & - \\
\hline $\begin{array}{l}\text { Durarak uzun } \\
\text { atlama testi }(\mathrm{cm})\end{array}$ & 101,80 & 24,46 & 105,76 & 15,27 & 104,89 & 27,57 & $\begin{array}{c}113,457 \\
46718,639 \\
46832,096\end{array}$ & $\begin{array}{c}56,729 \\
583,983\end{array}$ & 0,09 & 0,90 & - & - \\
\hline Mekik testi (n) & 15,90 & 6,47 & 15,68 & 4,50 & 13,56 & 4,81 & $\begin{array}{c}96,570 \\
1956,153 \\
2052,723\end{array}$ & $\begin{array}{l}48,285 \\
24,452\end{array}$ & 1,97 & 0,14 & - & - \\
\hline $\begin{array}{l}\text { Bükülü kol } \\
\text { asılma testi (sn) }\end{array}$ & 7,07 & 3,89 & 3,97 & 2,88 & 4,70 & 3,61 & $\begin{array}{c}69,034 \\
950,353 \\
1019,388\end{array}$ & $\begin{array}{l}34,517 \\
11,879\end{array}$ & 2,90 & 0,06 & - & - \\
\hline $\begin{array}{lr}\text { x10 metre } \\
\text { mekik koşusu } \\
\text { testi }(\mathrm{sn})\end{array}$ & 38,96 & 6,56 & 40,97 & 6,34 & 43,42 & 7,14 & $\begin{array}{c}214,365 \\
3750,304 \\
3964,669 \\
\end{array}$ & $\begin{array}{c}107,182 \\
46,879\end{array}$ & 2,28 & 0,10 & - & - \\
\hline
\end{tabular}

Öğrencilerin baba eğitim düzeyi açısından fiziksel uygunluk parametrelerinin karşılaştırmasında; boy uzunluğu, vücut ağırlığı, diske dokunma testi, otur-uzan testi, durarak uzun atlama testi, mekik testi, bükülü kol asılma testi, 5x10 metre mekik koşu testi değerlerinde anlamlı bir farklılık tespit edilememiştir ( $p>0.05)$. Baba eğitim düzeyi açısından flamingo denge skorlarında $\left[\mathrm{F}_{(2-82)}=3.61, p<0.05\right]$ anlamlı fark belirlenmiştir $(\mathrm{p}<0.05)$. Bu farkın; Scheffe post-doc analizi sonuçlarına göre ilköğretim mezunu olan baba ile ortaöğretim mezunu olan baba arasında olduğu ve farkın ortaöğretim mezunu olan baba lehine olduğu ancak, bu farkın etki büyüklüğünün ise düşük düzeyde olduğu tespit edilmiştir $\left(\eta^{2}=0.03\right)$ (Tablo 5).

Tablo 6. Öğrencilerin Fiziksel Uygunluk Parametrelerinin Aylık Ortalama Gelir ile İlişkisi

\begin{tabular}{|c|c|c|c|c|c|c|c|c|c|c|}
\hline Değişkenler & & 1 & 2 & 3 & 4 & 5 & 6 & 7 & 8 & 9 \\
\hline \multirow{2}{*}{ Aylık ortalama gelir (TL) } & $\mathrm{r}$ & $-0,00$ & 0,12 & 0,11 & 0,10 & $-0,30$ & $-0,12$ & $-0,12$ & $-0,01$ & $-0,04$ \\
\hline & $p$ & 0,97 & 0,24 & 0,30 & 0,32 & $0,00^{* *}$ & 0,26 & 0,26 & 0,90 & 0,67 \\
\hline
\end{tabular}

Öğrencilerin fiziksel uygunluk parametrelerinin aylık ortalama gelir ile ilişkisi incelendiğinde; esneklik değeri ile ayllk ortalama gelir arasında negatif yönlü zayıf bir ilişkisinin olduğu tespit edilmiştir $(r=-0.30$; $\mathrm{p}<0.05)$. Aylık ortalama gelir ile diğer fiziksel uygunluk parametreleri arasında bir ilişki tespit edilememiştir $(\mathrm{p}>0.05)$ (Tablo 6).

\section{TARTIŞMA ve SONUÇ}

$\mathrm{Bu}$ araştırma, ilkokulda öğrenim gören öğrencilerin; ailelerinin sosyo-ekonomik özelliklerini belirleyerek, bu etkenlerin öğrencilerin fiziksel uygunluk unsurlarına etkisini ortaya koymak amacı ile yapılmıştır. 
Araştırmada öğrencilerin fiziksel uygunluk unsurlarının anne eğitim düzeyi açsından karşılaştırmasında gruplar arasında anlamlı bir farklılık tespit edilmemiştir. İlköğretim mezunu, ortaöğretim mezunu ve yükseköğretim mezunu annelerin çocuklarının tüm fiziksel uygunluk parametrelerinde benzer puanlara sahip oldukları belirlenmiştir. Alpay (2011) çalısmasında, ilkokul mezunu annelerin kız çocuklarının vücut ağırlığının üniversite mezunu annelerin kız çocuklarının vücut ağırlı̆ıından daha düşük olduğunu ve ailelerin eğitim ve gelir düzeyi arttıkça kız çocuklarının vücut ağıllıklarının da arttığını tespit etmiştir. Ayrıca, yazar tarafindan eğitim düzeyi yüksek ailelerde vücut ağırlığının fazla olmasının bilinçsiz beslenmeden, eğitim düzeyi düşük ailelerde ise yetersiz beslenmeden kaynaklandığ1 savunulmaktadır. Akgün (1997) yurt dışında yaptığı çalışmada ise Suudi Arabistan, Brezilya ve Nijerya'da eğitimli aileden gelen çocukların yoksul ve eğitimsiz aileden gelen çocuklara oranla en az $2,5 \mathrm{~cm}$ boy ve $0,5 \mathrm{~kg}$ vücut ağırlığı fazlalığına sahip olduğunu bildirmektedir. Güler ve Günay (2004) anne eğitim seviyesine göre esneklik, mekik, dayanıklılık değerleri arasında eğitim seviyesi artıkça anlamlı bir ilişki olduğunu tespit etmiştir. Araştırma bulgularımız literatürde yapılan çalışmalar ile benzerlik göstermemektedir. Bu durumun, araştırma grubu sayısının az olmasından kaynaklı olabileceği düşünülmektedir. Araştırmada öğrencilerin fiziksel uygunluk unsurlarının baba eğitim düzeyi açısından karşılaştırmasında gruplar arasında denge düzeyleri açısından anlamlı bir fark tespit edilmiştir. Ortaokul mezunu babanın çocuklarının denge düzeyleri ilkokulu mezunu babanın çocuklarından daha yüksek olduğu belirlenmiştir. Diğer fiziksel uygunluk değişkenleri açısından gruplar arasında anlamlı farklılık tespit edilememiştir. Alpay (2011) baba eğitim düzeyine göre kız ve erkek çocukların vücut ağırlıklarında, boy uzunluklarında, deri kıvrım düzeylerinde, yatay sıçrama, denge performanslarına, 30 sn mekik, bükülü kol performanslarında istatistiksel olarak fark olduğu belirtilmiştir. Erden ve Oğuz (2009), eğitim düzeyi yüksek olan ailelerin çocuklarının flamingo denge testinde daha başarılı puanlara sahip olduğunu, eğitim seviyesi düşük olan ailelerin çocukların ise puanlarının daha düşük seviyede olduğunu ortaya koymuştur. Bu noktada, araştırma bulgularımızın literatürde yapılan çalışmalar ile benzerlik gösterdiği belirlenmiştir. Freitas ve diğ. (2007) ise ailelerinin düşük eğitim seviyesine sahip olan erkek çocuklarının otur-uzan testinde, ailelerinin orta ve yüksek eğitim grubunda olan olan yaşıtlarına göre daha iyi performans gösterdiğini belirlemişlerdir. Tekelioğlu (1999), düşük eğitim seviyesine ve düşük sosyo- ekonomik düzeye sahip çocukların daha fazla sokağa çıkma özgürlüğüne sahip olduklarını ifade etmekte ve böyle bir ortamda çocuğun fiziksel aktiviteleri daha fazla yapma ve motor becerilerini arttırma şansının olacağını vurgulamaktadır.

Araştırmada öğrencilerin fiziksel uygunluk unsurlarının aile aylık ortalama gelir ile ilişkisi incelendiğinde; otur-uzan testi ile negatif yönlü zayıf bir ilişki tespit edilmiştir. Ailenin aylık ortalama gelirinin artması ile öğrencilerin esneklik düzeylerinin azaldığı tespit edilmiştir. Kılıç (2007) otur-uzan ve testlinde, düşük sosyo-demografik gruptan olan erkek çocukların orta ve yüksek sosyo-demografik gruptan olan yaşıtlarına göre daha iyi performans gösterdiğini belirtmiştir. Tınazcı ve Emiroğlu (2010) genel olarak, yüksek sosyodemografik grupta bulunan katılımcıların, orta ve düşük sosyo-demografik gruptan katılımcılara göre daha uzun ve esnek olduğunu bildirmektedir. Öztürk (2019) ise sosyo-ekonomik durumu düşük olan okullarda öğrenim gören öğrencilerin flamingo denge testi, disklere vuruş testi, esneklik, pençe kuvveti, mekik, bükülü kol ile asılma ve 10x5 m mekik koşu testinde, özel okullarda öğrenim gören ve sosyo-ekonomik düzeyi yüksek olan öğrencilerden daha iyi olduklarını tespit etmiştir. Güler ve Günay (2004),sosyoekonomik düzeyin çocuklarda fiziksel uygunluğu etkilediğini ve yüksek sosyo-ekonomik düzeye sahip çocukların mekik kuvvet testinde daha yüksek, düşük sosyo-ekonomik düzeye sahip olanların ise barfiks kuvveti ve kardiyovasküler dayanıklılık testlerinde daha yüksek değerlere sahip olduklarını tespit etmişlerdir. Alpay (2011) ise yüksek gelir düzeye sahip ailelerin çocuklarının uzun atlama, denge, pençe kuvveti değerlerinin, alt ve orta gelir seviyesinden ailelerin çocuklarından daha yüksek olduğunu tespit etmiştir. Bernink ve diğ. (1983), yüksek sosyo-ekonomik düzeye sahip ailelerin çocuklarının daha uzun boylu olduklanını ve daha erken olgunlaştıklarını bildirmektedir. Yan (2007) ise düşük gelir ve orta gelir düzeyi grubundaki çocukların, yüksek gelir grubuna ait çocuklardan daha uzun olduğunu ortaya koymuştur. Diğer taraftan, sosyo-ekonomik durumu düşük olan çocukların fiziksel durumlarının daha iyi olduklarını gösteren çalışmalar da bulunmaktadır (Perez ve diğ., 1991). Yapılan bazı araştırmalarda insan 
büyümesi ve beden ölçüleri çevresel ortamın kalitesine duyarlı olduğu için, pozitif süreklilik arz eden eğilimler genellikle gelişmiş politik, sosyal koşullar ve iyi beslenme ve sağlık durumları ile bağdaştırılmış, negatif olanlar ise çoğunlukla çevresel, sosyal ve politik olarak kötü koşulların ürünü olarak düşünülmüştür (Pelletier, 2006; Ulijaszek, 2006)

Sonuç olarak, anne eğitim düzeyinin öğrencinin fiziksel uygunluk düzeylerini etkilemediği sonucuna varılmıştır. İlköğretim düzeyinde eğitim seviyesine sahip babaların çocuklarının daha iyi denge düzeyine sahip olduğu tespit edilmiştir. Bu bulgular doğrultusunda baba eğitim düzeyinin öğrencilerin sadece denge düzeyinde etkili olduğu sonucuna varılmıştır. Ailelerinin aylık ortalama gelirleri ile otur-uzan testi puanları arasında negatif yönlü zayıf bir ilişkinin olduğu tespit edilmiştir. Bu durum, ailenin aylık ortalama gelirlerindeki artış ile öğrencilerin esneklik düzeylerinde zayıf düzeyde olsa bir azalma olacağı şeklinde yorumlanabilir.

\section{KAYNAKLAR}

Akgün, S. H. (1997). Sosyo-Ekonomik Yönden Farkl İki Ilkokul Ögrrencilerinin Fizik Büyüme Durumlar ve Etkileyen Bazı Faktörlerin Araștırlması. Doktora tezi, Hacettepe Üniversitesi Sağlık Bilimleri Enstitüsü, Ankara.

Alpay, N. (2011). 12-14 Yaş Adolesanlarn Fizilesel Uygunluk Özelliklerinin Ailelerin Sosyo-demografik Özelliklerine göre İncelenmesi (Ankara İli Örnĕgi). Yayımlanmamış doktora tezi, Gazi Üniversitesi Eğitim Bilimleri Enstitüsü, Ankara.

Altınkök, M. (2006). Temel Motor Hareketlerinin Geliştirilmesini İçeren Öz̨el Beden Eğitimi Program Tasarısmm 5-6 yaş Cocuklarm Temel Motor Hareketlerinin Gelişimine Etkisinin Araștırlması. Yüksek lisans tezi, Marmara Üniversitesi Eğitim Bilimleri Enstitüsü, İstanbul.

Ballı, Ö. M. (2006). Bruininks-Oseretsky Motor Yeterlik. Testinin Geçerlik, Güvenirlik Calışması ve Beş-Altı Yaș Grubu Cocuklara Uygulanan Jimnastike Eğitim Programını Motor Gelişime Etkisinin Incelenmesi. Doktora tezi, Ankara Üniversitesi Fen Bilimleri Enstitüsü, Ankara

Bayraktar, R. (2001). Davranış Bilimlerine Giriş. Eskişehir: Anadolu Üniversitesi Web-Ofset

Bernink, M., Erich, W., Peltenburg, A., Zonderlanf, M. and Huisveld, I. (1983). Height, body composition, biological maturation and training in relation to socio-economic status in girl gymnasts, swimmers, and controls. Growth, 47(1), 1-12.

Büyüköztürk, Ş., Çakmak, E. K., Akgün, Ö. E., Karadeniz, Ş. ve Demirel, F. (2016). Bilimsel Araștırma Yöntemleri. 21. Bask1. Ankara: Pegem Akademi.

Erden, S. ve Oğuz, H. (2009). Bursa ilinde farklı sosyo-ekonomik düzeye sahip aile çocuklarının fiziksel performans özelliklerinin incelenmesi. Ë̆itim Fakültesi Dergisi, 22(1), 279-292.

Freitas, D., Maia, J., Beunen, G., Claessens, A., Thomis, M., Marques, A., Crespo, M. and Lefevre, J. (2007). Socio-economic status, growth, physical activity and fitness: The madeira growth study. Annals of Human Biology, 34(1), 107-122.

Goslin, B. R. And Burden, S. B. (1986). Physical fitness of South African school children. The Journal of Sports Medicine and Physical Fitness, 26(2), 128-136.

Güler, D. ve Günay, M. (2004). Çocuklarda sosyoekonomik düzeyin fiziksel uygunluğa etkisinin AAHPERD fiziksel uygunluk test bataryası ile değerlendirilmesi. Abi Evran Üniversitesi Kırşehir Eğitim Fakültesi Dergisi, 5(1).

Hazar, F. ve Taşmektepligil, Y. (2008). Puberte öncesi dönemde denge ve esnekliğin çeviklik üzerine etkilerinin incelenmesi. Spormetre Beden Ë̈itimi ve Spor Bilimleri Dergisi, 5(1), 9-12.

Himes, J. H. (2006). Long-term longitudinal studies and implications for the development of an international growth reference for children and adolescents. Food and Nutrition Bulletin, 27(4), 199-211.

Kandır, A. ve Tümer, K. (2013). Farklı sosyo-ekonomik düzeydeki beş-altı yaş çocuklarının erken öğrenme becerilerinin incelenmesi. Sosyal Politika Calışmalar, 13(7).

Karakoç, B. (2009). Genç Futbolcularda Sıklıkla Kullanılan Alan Testlerinin Aerobik ve Anaerobik Yapılarmm Incelenmesi. Yayımlanmamış yüksek lisans tezi, Ankara Üniversitesi Sağlık Bilimleri Enstitüsü, Ankara.

Kılıç, C. (2007). İlkëğretim Birinci Kademe Öğrencilerinin Bą̧ Fiz̨iksel Uygunluk Seviyelerinin Karşılaştırlması. Yayımlanmamış yüksek lisans tezi, Gazi Üniversitesi Sağlık Bilimleri Enstitüsü, Ankara.

Malina, R.M., Bouchard, C. and Bar-or, O. (2004). Growth, Maturation, and Physical Activity. Human Kinetics.

Muratlı, S. (2007). Antrenman Bilimi Yaklaşımıla Cocuk ve Spor. Ankara: Nobel Yayın Dağıtım.

Oğuz, H. (1998). Bursa Ilinde Farkh Sosyo-Ekonomik Düzeye Sabip Ailelerin 8, 9 ve 10 Yaș Grubu Cocuklarm Fiziksel Performans ve Antropometrik Özelliklerinin Incelenmesi. Yüksek lisans tezi, Uludă̆ Üniversitesi Sosyal Bilimler Enstitüsü, Bursa. 
Opstoel, K., Pion, J., Elferink-Gemser, M., Hartman, E., Willemse, B., Philippaerts, R.and Lenoir, M. (2015). Anthropometric characteristics, physical fitness and motor coordination of 9 to 11 year old children participating in a wide range of sports. PloS One, 10(5).

Özer, D. ve Özer, K. (2002). Çocuklarda Motor Gelişim. Geliştirilmiş 2. Baskı. Ankara: Nobel Yayın Evi.

Öztürk, Y. (2019). 10-12 Yass Aralğgndaki Öğrencilerin Fiq̨iksel Uygunluke ve Demografik Durumlarmm Sosyal Becerileri Ürerindeki Etkisinin Araştırlması (Van İli Örneğgi). Yayımlanmamış yüksek lisans tezi, Van Yüzüncü Yıl Üniversitesi Eğitim Bilimleri Enstitüsü, Van.

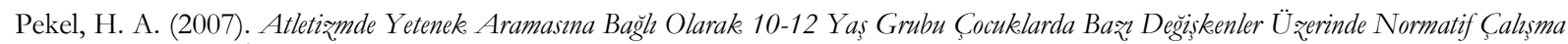
(Ankara İli Örneği). Doktora tezi, Gazi Üniversitesi Sağlık Bilimleri Enstitüsü, Ankara.

Pelletier, T. (2006). Theoretical considerations related to cutoff points. Food and Nutrition Bulletin. 27(4), 224-236.

Pérez, G. E. N., D’Angelo, C. P. And Zabala, R. D. (1991). Physical Fitness in Children and Adolescents from Differing Socioeconomic Strata. In Human growth, physical fitness and nutrition (Vol. 31, pp. 80-98). Karger Publishers.

Saygın, Ö. Ve Özşaker, M. (2012). Bireysel ve takım sporcuların bazı fiziksel uygunluklarının özelliklerinin karşısştırılması. Niğde Üniversitesi Beden Eğitimi ve Spor Bilimleri Dergisi, 6, 2.

Tabachnick, B. G. and Fidell, L. S. (2013). Using Multivariate Statistics. 6. Bask1. Boston: Allyn and Bacon.

Tekelioğlu, A. (1999). Devlet Okulu ve Özel Okulda Okuyan 11-13 Yaş Grubu Kız ve Erkek Çocukların Fiziksel Uygunlukları. Yayınlanmamış doktora tezi, Gazi Üniversitesi Sağlık Bilimleri Enstitüsü, Ankara.

Tinazc1, C. and Emiroğlu, O. (2010). Assessment of physical fitness levels, gender and age differences of rural and urban elementary school children. Turkiye Klinikleri J Med Sci, 30(1), 1-7.

Ulijaszek, S. J. (2006). The international growth standard for children and adolescents project: environmental influences on preadolescent and adolescent growth in weight and height. Food and Nutrition Bulletin, 27(4), 279-294.

Yan, Y. (2007). 10-13 Yaş Cocuklarda, Sosyo-Ekonomik Yapınm Fizilksel Aktivite ve Fiæilksel Uygunluk Düzeyine Etkisi. Yayımlanmamış yüksek lisans tezi, Marmara Üniversitesi Sağlık Bilimleri Enstitüsü, İstanbul.

Yıldız, İ. (2009). Farkh Dirençlerle Uygulanan Kuvvet Antrenmanlarmm Kız Cocuklarmmn Fižiksel ve Kas-Kuvvet Gelişimlerine Olan Etkisinin İncelenmesi. Yüksek lisans tezi, Marmara Üniversitesi Sağllk Bilimleri Enstitüsü, İstanbul.

Yüzgül, A. ve Müniroğlu, S. (2001). Ankara'da Özel Bir Okulda 7-12 Yaş Grubu Çocukların Fiziksel Özelliklerinin İncelenmesi. 3. Uluslararası Akdeniz Spor Bilimleri Kongresi, Antalya.

Zahner, L., Puder, J. J., Roth, R., Schmid, M., Guldimann, R., Pühse, U., Knöpfli, M., Braun-Fahrlander, C., Marti, B. and Kriemler, S. A. (2006). School-based physical activity program to improve health and fitness in children aged 6-13 years "Kinder Sport studie KISS": Study design of a randomized controlled trial. BMC Public Health, 6(6), 14. 